\title{
3,4,3-LI(1,2-HOPO): In Vitro Formation of Highly Stable Lanthanide Complexes Translates into Efficacious In Vivo Europium Decorporation Manuel Sturzbecher-Hoehne, ${ }^{a}$ Clara Ng Pak Leung, ${ }^{a}$ Anthony D'Aléo, ${ }^{a}$ Birgitta Kullgren, ${ }^{a}$ Anne-Laure Prigent, ${ }^{a}$ David K. Shuh, ${ }^{a}$ Kenneth N. ${ }_{s}$ Raymond $^{a, b}$ and Rebecca J. Abergel ${ }^{* a}$
}

\section{DISCLAIMER}

${ }_{10}$ This document was prepared as an account of work sponsored by the United States Government. While this document is believed to contain correct information, neither the United States Government nor any agency thereof, nor the Regents of the University of California, nor any of their employees, makes any warranty, express or implied, or assumes any legal responsibility for the accuracy, completeness, or usefulness of any information, apparatus, product, or process disclosed, or represents that its use would not infringe privately owned rights. Reference herein to any specific commercial product,

15 process, or service by its trade name, trademark, manufacturer, or otherwise, does not necessarily constitute or imply its endorsement, recommendation, or favoring by the United States Government or any agency thereof, or the Regents of the University of California. The views and opinions of authors expressed herein do not necessarily state or reflect those of the United States Government or any agency thereof or the Regents of the University of California.

\section{${ }_{20}$ FUNDING}

This work was supported by the National Institutes of Health (grant 1RC2AI087604-01), and the Director, Office of Science, Office of Basic Energy Sciences, Division of Chemical Sciences, Geosciences, and Biosciences of the U.S. Department of Energy at Lawrence Berkeley National Laboratory under Contract No. DE-AC02-05CH11231. 


\title{
3,4,3-LI(1,2-HOPO): In Vitro Formation of Highly Stable Lanthanide Complexes Translates into Efficacious In Vivo Europium Decorporation
}

\author{
Manuel Sturzbecher-Hoehne, ${ }^{a}$ Clara Ng Pak Leung, ${ }^{a}$ Anthony D'Aléo, ${ }^{a}$ Birgitta Kullgren, ${ }^{a}$ Anne-Laure \\ ${ }_{5}$ Prigent, ${ }^{a}$ David K. Shuh, ${ }^{a}$ Kenneth N. Raymond ${ }^{a, b}$ and Rebecca J. Abergel ${ }^{* a}$
}

The spermine-based hydroxypyridonate octadentate chelator 3,4,3-LI(1,2-HOPO) was investigated for its ability to act as an antennae that sensitizes the emission of $\mathrm{Sm}^{\mathrm{III}}, \mathrm{Eu}^{\mathrm{III}}$, and $\mathrm{Tb}^{\mathrm{III}}$ in the Visible range $\left(\Phi_{\text {tot }}\right.$ $10=0.2-7 \%$ ) and the emission of $\mathrm{Pr}^{\mathrm{III}}, \mathrm{Nd}^{\mathrm{III}}, \mathrm{Sm}^{\mathrm{III}}$, and $\mathrm{Yb}^{\mathrm{III}}$ in the Near Infra-Red range, with decay times varying from $1.78 \mu$ s to $805 \mu$ s at room temperature. The particular luminescence spectroscopic properties of these lanthanide complexes formed with 3,4,3-LI(1,2-HOPO) were used to characterize their respective solution thermodynamic stabilities as well as those of the corresponding $\mathrm{La}^{\mathrm{III}}, \mathrm{Gd}^{\mathrm{III}}, \mathrm{Dy}^{\mathrm{III}}, \mathrm{Ho}^{\mathrm{III}}, \mathrm{Er}^{\mathrm{III}}$, $\mathrm{Tm}^{\mathrm{III}}$, and $\mathrm{Lu}^{\mathrm{III}}$ complexes. The remarkably high affinity of 3,4,3-LI(1,2-HOPO) for lanthanide metal ions 15 and the resulting high complex stabilities (pM values ranging from 17.2 for $\mathrm{La}^{\mathrm{III}}$ to 23.1 for $\mathrm{Yb}^{\mathrm{III}}$ ) constitute a necessary but not sufficient criteria to consider this octadentate ligand an optimal candidate for in vivo metal decorporation. The in vivo lanthanide complex stability and decorporation capacity of the ligand were assessed, using the radioactive isotope ${ }^{152} \mathrm{Eu}$ as a tracer in a rodent model, which provided a direct comparison with the in vitro thermodynamic results and demonstrated the great potential of 3,4,3${ }_{20} \mathrm{LI}(1,2-\mathrm{HOPO})$ as a therapeutic metal chelating agent.

\section{Introduction}

Siderophore-inspired multidentate hydroxypyridonate ligands can be used in a variety of applications such as magnetic resonance imaging (MRI) contrast enhancement, lanthanide luminescence sensitization, and iron and actinide chelation. ${ }^{1-5}$ The octadentate ligand 3,4,3-LI(1,2-HOPO) (Fig. 1), composed of four 1-hydroxy-pyridin-2-one (1,2-HOPO) units linked to a spermine scaffold through amide ${ }_{25}$ linkages, is currently considered the most efficient experimental decorporation agent for actinides. ${ }^{1,6,7}$ Studies have shown that this ligand is orally active and is by far more efficacious than the commonly used diethylenetriamine-pentaacetic acid (DTPA, Fig. 1) at promoting the in vivo decorporation of actinide metal ions, such as $\mathrm{U}^{\mathrm{VI}}, \mathrm{Np}^{\mathrm{V}}, \mathrm{Pu}^{\mathrm{IV}}$, and $\mathrm{Am}^{\mathrm{III}}$. 6-8 In addition, 3,4,3-LI(1,2-HOPO) is known to act as an antenna that sensitizes the luminescence of $\mathrm{Eu}^{\mathrm{III}}$, a feature that was used recently to determine the solution thermodynamic stability of the corresponding $\left[\mathrm{Eu}^{\mathrm{III}}(3,4,3-\mathrm{LI}(1,2-\mathrm{HOPO}))\right]^{\urcorner}$complex. ${ }^{9}$ In the work presented here, the photophysical properties of the complexes of 30 3,4,3-LI(1,2-HOPO) formed with metal ions from the whole lanthanide series were probed and characteristic emission sensitization was observed in both the Visible and Near Infra-Red ranges, depending on the complexed metal ion. The use of the antenna effect as a spectroscopic tool was extended to spectrofluorimetric competition titrations, to determine the formation constants of these lanthanide complexes. While such thermodynamic parameters are essential to characterize 3,4,3-LI(1,2-HOPO) as a chelating agent and compare its affinity to different metal ions, they are only indicative of the potential in vivo decorporation efficacy of the ligand. The in vivo Eu ${ }^{\text {III }}$ ${ }_{35}$ complex stability and $\mathrm{Eu}^{\mathrm{III}}$ decorporation capacity of 3,4,3-LI(1,2-HOPO) were therefore also assessed in mice, using the radioactive isotope ${ }^{152} \mathrm{Eu}$ as a contaminant, which provides a direct comparison with the in vitro thermodynamic results.

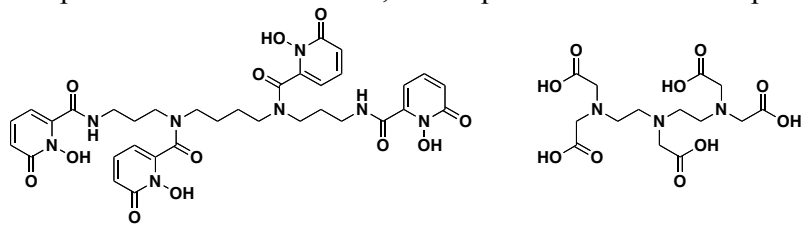

Fig. 1 Structures of the experimental octadentate ligand 3,4,3-LI(1,2,-HOPO) (left) and the approved decorporation agent DTPA (right).

\section{${ }_{40}$ Experimental}

\section{General considerations}

All chemicals were obtained from commercial suppliers and used as received. The $\mathrm{Ln}^{\mathrm{III}}$ salts utilized were of the highest purity available (>99.9\%). The ligand 3,4,3-LI(1,2-HOPO) was synthesized by Synthetech, Inc. (Albany, OR, USA), following previously reported procedures, and used as received. A Millipore Milli-Q Advantage A10 Water System Production Unit was used to purify deionized 45 water. 


\section{Photophysics.}

UV-Visible absorption spectra were recorded either on a Varian Cary 300 double beam absorption spectrometer or Ocean Optics USB 4000 , using quartz cells of $1.00 \mathrm{~cm}$ path length. Emission spectra were acquired on a HORIBA Jobin Yvon IBH FluoroLog-3 spectrofluorimeter, equipped with 3 slit double grating excitation and emission monochromators $(2.1 \mathrm{~nm} / \mathrm{mm}$ dispersion, 1200 ${ }_{5}$ grooves $/ \mathrm{mm}$ ). Spectra were reference corrected for both the excitation light source variation (lamp and grating) and the emission spectral response (detector and grating). Luminescence lifetimes were determined on a HORIBA Jobin Yvon IBH FluoroLog-3 spectrofluorimeter, adapted for time-correlated single photon counting (TCSPC) and multichannel scaling (MCS) measurements. A submicrosecond Xenon flashlamp (Jobin Yvon, 5000XeF) was used as the lightsource, with an input pulse energy (100 $\mathrm{nF}$ discharge capacitance) of ca. $50 \mathrm{~mJ}$, yielding an optical pulse duration of less than $300 \mathrm{~ns}$ at FWHM. Spectral selection was achieved by passage

10 through a double grating excitation monochromator $(2.1 \mathrm{~nm} / \mathrm{mm}$ dispersion, 1200 grooves $/ \mathrm{mm})$. Emission was monitored perpendicular to the excitation pulse, again with spectral selection achieved by passage through a double grating excitation monochromator (2.1 $\mathrm{nm} / \mathrm{mm}$ dispersion, 1200 grooves $/ \mathrm{mm}$ ). A thermoelectrically cooled single photon detection module (HORIBA Jobin Yvon IBH, TBX04-D) incorporating fast rise time PMT, wide bandwidth preamplifier and picosecond constant fraction discriminator was used as the detector. Signals were acquired using an IBH DataStation Hub photon counting module and data analysis was performed using the 15 commercially available DAS 6 decay analysis software package from HORIBA Jobin Yvon IBH. Goodness of fit was assessed by minimizing the reduced chi squared function, $\chi^{2}$, and a visual inspection of the weighted residuals. Each trace contained at least 5,000 points, and the estimated error on the reported lifetime values is $\pm 10 \%$. Quantum yields and kinetic parameters were determined as previously described. ${ }^{9}$

\section{Mass Spectrometry Analysis}

20 Mass spectra were obtained on an Agilent Technologies 6120 Quadrupole MS equipped with an electrospray ionization source. For direct injection, a syringe pump (KD Scientific) delivered the samples to the mass spectrometer with a constant flow rate of $83 \mu \mathrm{L} / \mathrm{min}$. The voltage applied to the capillary was $3.2 \mathrm{kV}$ in the negative detection mode. A nitrogen gas flow rate of $12 \mathrm{~L} / \mathrm{min}$ was used to assist the nebulization process. The cone voltage was set in negative $50 \mathrm{~V}$ and the ion source temperature was $150{ }^{\circ} \mathrm{C}$. Mass spectra were recorded over a $50-1100 \mathrm{~m} / \mathrm{z}$ range. The $\mathrm{pH}$ of each injected solution was measured with a conventional $\mathrm{pH}$ meter at $25^{\circ} \mathrm{C}(713 \mathrm{pH}$ meter, 25 Metrohm Brinkmann) that was equipped with a glass electrode (Micro Combi Electrode, Metrohm) filled with $\mathrm{KCl}$ and calibrated with $\mathrm{pH}$ standards. All samples were prepared in purified deionized water and special care was taken to adjust the $\mathrm{pH}$ to $7.4 \mathrm{with} \mathrm{KOH}$ (other bases and buffers may yield to additional peaks in the mass spectra).

\section{Solution Thermodynamics: General Considerations}

A Micro Combi Electrode (Metrohm) glass electrode (response to $\left[\mathrm{H}^{+}\right]$was calibrated before each titration) ${ }^{10}$ was used with a Metrohm ${ }_{30}$ Titrando 907 (Metrohm) to measure the $\mathrm{pH}$ of the experimental solutions. The Metrohm autoburet adds incremental volumes of acid or base standard solutions to the titration cell. The titration instruments were fully automated and controlled using the Tiamo software from Metrohm. Titrations were performed in $0.1 \mathrm{M} \mathrm{KCl}$ supporting electrolyte under positive Ar gas pressure. The temperature of the experimental solutions was maintained at $25{ }^{\circ} \mathrm{C}$ by an external circulating water bath. Luminescence spectra for direct spectrofluorimetric titrations were recorded on an Ocean Optics USB 4000 spectrophotometer (slit $50 \mathrm{~mm}$, grating 600 grooves/mm, 35 blaze $400 \mathrm{~nm}$ ) equipped with a PX-2 pulsed xenon or HPX-2 high-powered xenon light source. Samples were pumped trough a loop in an asymmetric fluorescence cell $(2 \times 10 \mathrm{~mm}, 40 \mathrm{ml})$ with a peristaltic pump after adding the increment of reagent. All titrant solutions were prepared using distilled water that was further purified by passing through a Millipore Milli-Q reverse osmosis cartridge system. Titrants were degassed by boiling for $1 \mathrm{~h}$ while being purged under Ar. Carbonate-free 0.1 M KOH was prepared from Baker Dilut-It concentrate and was standardized by titrating against $0.1 \mathrm{M} \mathrm{HCl}$. Solutions of $0.1 \mathrm{M} \mathrm{HCl}$ were similarly prepared and were standardized

40 by titrating against TRIS. Stock solutions of 3,4,3-LI(1,2-HOPO) were obtained by dissolving in Milli-Q water. Stock solutions of lanthanide ions were obtained by dissolving solid $\mathrm{LnCl}_{3} \cdot \mathrm{nH}_{2} \mathrm{O}$ in standardized $1 \mathrm{M} \mathrm{HCl}$.

\section{$\mathrm{Eu}^{\mathrm{III}}$ Complex: Incremental Spectrofluorimetric Titrations}

Solutions were assembled from stock solutions of ligand, a measured aliquot of the europium stock solution and the supporting electrolyte solution, with resulting ligand and europium concentrations of $\sim 50 \mu \mathrm{M}$, and were incrementally perturbed by the addition of 45 titrant, followed by a time delay for equilibration (180 seconds). Buffering of the solution was assured by the addition of acetic acid, HEPES and MES buffers (10 mM). An average of 120-150 data points were collected in each pair of complex titrations, each data point consisting of a $\mathrm{pH}$ measurement and luminescence spectra over the $\mathrm{pH}$ range 1.4 to 10.5 . Nonlinear least-squares refinement of the complex formation constants was performed using the program pHab. $^{10-14}$

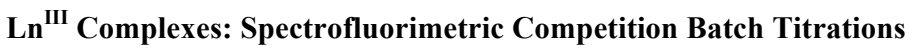

${ }_{50}$ Varying volumes of a $\mathrm{Ln}^{\mathrm{III}}$ stock solution were added to solutions of ligand $(0.03 \mathrm{mM})$ and europium $(0.03 \mathrm{mM})$ in $0.1 \mathrm{M} \mathrm{KCl}$ buffered at $\mathrm{pH} 7.4$ with 0.1 M HEPES. All solutions were diluted to identical volumes to reach final concentrations of ligand and europium of $0.005 \mathrm{mM}$. The ranges of $\mathrm{Eu}^{\mathrm{III}}: \mathrm{Ln}^{\mathrm{III}}$ used in each competition titrations were: 1:0 to 1:1000 for $\mathrm{La}^{\mathrm{III}}, 1: 0$ to $1: 100 \mathrm{for} \mathrm{Pr}^{\mathrm{III}}$ and $\mathrm{Nd}^{\mathrm{III}}$, and 1:0 to $1: 10$ for $\mathrm{Ln}^{\mathrm{III}}=\mathrm{Sm}^{\mathrm{III}}-\mathrm{Lu}^{\mathrm{III}}$.

Table 1 Photophysical and Thermodynamic Parameters for [ $\left.\operatorname{Ln}^{\mathrm{III}}(3,4,3-\mathrm{LI}(1,2-\mathrm{HOPO}))\right]^{-}$at $\mathrm{pH}$ 7.4. ${ }^{\text {[a] }}$ 


\begin{tabular}{|c|c|c|c|c|c|c|c|c|c|c|c|c|c|}
\hline $\mathrm{Ln}$ & $\mathrm{La}^{[\mathrm{b}]}$ & $\operatorname{Pr}^{[c]}$ & $\mathrm{Nd}^{[\mathrm{c}]}$ & $\mathrm{Sm}$ & $\mathrm{Eu}$ & $\mathrm{Gd}^{[\mathrm{d}]}$ & $\mathrm{Tb}$ & $D y^{[e]}$ & $\mathrm{Ho}^{[\mathrm{e}]}$ & $\mathrm{Er}^{[\mathrm{e}]}$ & $\operatorname{Tm}^{[\mathrm{d}]}$ & $\mathrm{Yb}^{[\mathrm{c}]}$ & $\mathrm{Lu}^{[\mathrm{f}]}$ \\
\hline $\mathrm{n},[\mathrm{Xe}] 4 f^{\mathrm{n}}$ & 0 & 2 & 3 & 5 & 6 & 7 & 8 & 9 & 10 & 11 & 12 & 13 & 14 \\
\hline \multicolumn{14}{|c|}{ Photophysical Parameters } \\
\hline$\lambda_{\max }(\mathrm{nm})$ & 320 & 316 & 317 & 316 & 315 & 316 & 316 & 315 & 315 & 315 & 315 & 315 & 314 \\
\hline $\begin{array}{l}\varepsilon_{\max }\left(\mathrm{M}^{-1} \mathrm{~cm}^{-1}\right) \\
\Phi_{\text {tot }}\end{array}$ & 16,460 & 17,080 & 17,220 & $\begin{array}{l}17,850 \\
0.002(1)\end{array}$ & $\begin{array}{l}17,740 \\
0.07(1)^{[\mathrm{g}]}\end{array}$ & 17,830 & $\begin{array}{l}17,810 \\
0.002(1)\end{array}$ & 17,470 & 17,790 & 17,620 & 17,790 & 17,880 & 16,760 \\
\hline \multicolumn{14}{|c|}{ Thermodynamic Parameters } \\
\hline $\log K_{\mathrm{ML}}$ & $16.4(3)$ & $18.2(4)$ & $18.7(1)$ & $19.7(3)$ & $20.2(2)$ & $20.5(1)$ & $20.9(1)$ & $21.2(1)$ & $21.5(1)$ & $21.7(1)$ & $22.0(1)$ & $22.2(1)$ & $21.2(1)$ \\
\hline $\mathrm{pM}^{\ddagger}$ & $17.2(3)$ & $19.0(4)$ & $19.6(1)$ & $20.6(3)$ & $21.1(2)^{[\mathrm{g}]}$ & 21.3(1) & $21.8(1)$ & 22.1(1) & $22.4(1)$ & $22.6(1)$ & $22.9(1)$ & 23.1(1) & $22.0(1)$ \\
\hline$\Delta \mathrm{pM}^{[\mathrm{h}]}$ & -3.9 & -2.1 & -1.5 & -0.5 & 0 & 0.2 & 0.7 & 1.0 & 1.3 & 1.5 & 1.8 & 2.0 & 0.9 \\
\hline
\end{tabular}

[a] The figures in parentheses give the uncertainty determined from the standard deviation between three independent measurements, all values reported are for $I=0.1 \mathrm{M} \mathrm{(KCl)}$; [b] no f electron; [c] no reference in the NIR to calculate $\phi_{\text {tot }}$; $[\mathrm{d}$ ] no sensitization possible; [e] no sensitization observed; [f] full electron shell; $[\mathrm{g}]$ previously reported ${ }^{9} ;[\mathrm{h}]\left[\mathrm{Eu}^{\mathrm{III}}(3,4,3-\mathrm{LI}(1,2-\mathrm{HOPO}))\right]^{-}$is used as a reference with a $\mathrm{pM}^{\ddagger}$ value of 21.1 .

All samples were equilibrated in a thermostatic shaker at $25{ }^{\circ} \mathrm{C}$ until equilibrium was reached and measurements were stable (5 d). The ${ }_{5}$ emission spectrum of each solution was measured using a $1-\mathrm{cm}$ quartz cell $\left(\lambda_{\mathrm{exc}}=325 \mathrm{~nm}, \lambda_{\mathrm{em}}=570-720 \mathrm{~nm}\right)$. The data was then imported into the refinement program HypSpec ${ }^{10-15}$ and analyzed by nonlinear least-squares refinement.

\section{Solution Thermodynamics: Data Treatment}

All equilibrium constants were defined as cumulative formation constants, $\beta_{m l h}$ according to Eq. 1 , where the metal and ligand are designated as $\mathrm{M}$ and $\mathrm{L}$, respectively.

$m \mathrm{M}+l \mathrm{~L}+h \mathrm{H} \leftrightarrow\left[M_{m} \mathrm{~L}_{l} \mathrm{H}_{h}\right] ; \beta_{m l h}=\frac{\left[M_{m} \mathrm{~L}_{l} \mathrm{H}_{h}\right]}{[\mathrm{M}]^{m}[\mathrm{~L}]^{l}[\mathrm{H}]^{h}}$

Eq.1

All metal and ligand concentrations were held at estimated values determined from the volume of standardized stock solutions. The refinements of the overall formation constants $\beta_{110}$ and $\beta_{111}$ included in each case the four previously determined ligand protonation 15 constants $^{9}$ and the metal hydrolysis products, for which equilibrium constants were fixed to the literature values ${ }^{16}$ (Table 2 and ESI $^{\dagger}$ Table S1); all ligand species formed with $\mathrm{Eu}^{\mathrm{III}}, \mathrm{Sm}^{\mathrm{III}}$ or $\mathrm{Tb}^{\mathrm{III}}$ were considered to have significant emission to be observed in the emission spectra. The $\mathrm{pM}\left(\mathrm{Ln}^{\mathrm{III}}\right)^{\ddagger}$ values were calculated using the modelling program Hyss. ${ }^{17,18}$

\section{In Vivo Evaluation: General Considerations}

All procedures and protocols used in the presented in vivo studies were reviewed and approved by the Institutional Animal Care and Use

${ }_{20}$ Committee of the Lawrence Berkeley National Laboratory and were performed in AAALAC accredited facilities. The animals used were young adult female Swiss-Webster mice ( $87 \pm 9$ days old, $32 \pm 2 \mathrm{~g}$ ). After injection of a ${ }^{152}$ Eu tracer, mice were weighed, identified, and housed in groups of five in plastic stock

cages lined with a $0.5 \mathrm{~cm}$ layer of highly absorbent low-ash pelleted cellulose bedding (Alpha-dry) for separation of urine and feces. All mice were given water and food $a b$ libitum and were euthanized at $24 \mathrm{~h}$ after the tracer injection. All experiments using ${ }^{152} \mathrm{Eu}$ tracers

${ }_{25}$ were managed as metabolic balance studies, in which blood, all tissues, and excreta were analyzed for ${ }^{152}$ Eu by liquid scintillation counting on a Perkin Elmer Packard Tri-Carb model B4430. The methods of sample collection, preparation, radioactivity measurements, and data reduction have been published previously. ${ }^{19,7,20,21}$ Those methods provide quantitative measurements of the radioactivity in the biological samples and material recoveries are about $95 \%$ of the amount injected.

\section{Decorporation Efficacy Assay}

30 Ligand solutions were prepared such that the selected dosage $\left(30 \mu \mathrm{mol} \mathrm{kg}{ }^{-1}\right)$ was contained in $0.5 \mathrm{~mL}$ of $0.14 \mathrm{M} \mathrm{NaCl}$, the $\mathrm{pH}$ being adjusted to 7.4-8.4 with $1 \mathrm{~N} \mathrm{NaOH}$. Under isoflurane anesthesia, groups of five normally fed mice were injected in a lateral tail vein with $0.2 \mathrm{~mL}$ of the tracer solution containing ${ }^{152} \mathrm{Eu}(1.7 \mathrm{kBq}, 0.024 \mathrm{ng})$ in $0.008 \mathrm{M}$ sodium citrate and $0.14 \mathrm{M} \mathrm{NaCl}$, pH 4 . Ligands were administered by intraperitoneal injection at $1 \mathrm{~h}$ after the tracer injection. Isotonic saline was administered to control animals.

\section{In Vivo Complex stability Assay}

${ }_{35}$ The ${ }^{152} \mathrm{Eu}$ complexes of DTPA and 3,4,3-LI(1,2-HOPO) were prepared in situ at molar ratio ligand: ${ }^{152}$ Eu $>20$ by mixing and incubating the appropriate quantities of ${ }^{152} \mathrm{EuCl}_{3}$ and ligand in $0.14 \mathrm{M} \mathrm{NaCl}$ to reach a ${ }^{152} \mathrm{Eu}$ concentration of $0.12 \mu \mathrm{g} \mathrm{L} \mathrm{L}^{-1}$. Under isoflurane anesthesia, groups of five normally fed mice were injected intraperitoneally with $0.2 \mathrm{~mL}$ of a complex solution (1.7 kBq per mouse).

$40 \$ \mathrm{pM}$ is the $-\log [$ free $\mathrm{M}]$ for the specific set of conditions $[$ Metal $]=10^{-6} \mathrm{M},[$ Ligand $]=10^{-5} \mathrm{M}, \mathrm{pH} 7.4$. 


\section{Results and discussion}

\section{Photophysical Characterization}

The photophysical parameters for the lanthanide complexes $\left[\mathrm{Ln}^{\mathrm{III}}(3,4,3-\mathrm{LI}(1,2-\mathrm{HOPO}))\right]^{-}$( $\mathrm{Ln}$ from $\mathrm{La}^{\mathrm{III}}$ to $\mathrm{Lu}^{\mathrm{III}}$, excluding Pm ${ }^{\mathrm{III}}$ and ${ }_{5} \mathrm{Ce}^{\mathrm{III}} ; \mathrm{Pm}^{\mathrm{III}}$ was excluded due to its radioactivity while $\mathrm{Ce}^{\mathrm{III}}$ was excluded because of its reduction/oxidation properties) were measured in buffered aqueous solutions at $\mathrm{pH} 7.4$ and are summarized in Table 1. The electronic absorption spectra show a shift towards the higher energies along the lanthanide series, with an absorption maximum due to the ligand $\pi \rightarrow \pi^{*}$ transitions that ranges from $\lambda_{\max }=320 \mathrm{~nm}$ for La to $\lambda_{\max }=314$ for Lu (See ESI ${ }^{\dagger}$ Fig. S1). Luminescence spectra were recorded for all complexes with the same excitation wavelength $\lambda_{\text {exc }}=325 \mathrm{~nm}$.

10

Fig. 2 Luminescence spectra in buffered aqueous solutions, $\mathrm{pH}=7.4,0.1 \mathrm{M}$ HEPES, $\lambda_{\mathrm{exc}}=325 \mathrm{~nm}$ of: $\left.\mathbf{A}\right)\left[\mathrm{Sm}{ }^{\mathrm{III}}(3,4,3-\mathrm{LI}(1,2-\mathrm{HOPO})]^{-}\right.$(solid) and $\left[\mathrm{Tb}^{\mathrm{III}}(3,4,3-\mathrm{LI}(1,2-\mathrm{HOPO}))\right]^{-}$(dash); B) [Pr $\left.{ }^{\mathrm{III}}(3,4,3-\mathrm{LI}(1,2-\mathrm{HOPO}))\right]^{-}$(dash), [Nd $\left.{ }^{\mathrm{III}}(3,4,3-\mathrm{LI}(1,2-\mathrm{HOPO}))\right]^{-}$(dot), [Sm $\left.{ }^{\mathrm{III}}(3,4,3-\mathrm{LI}(1,2-\mathrm{HOPO}))\right]^{-}$(solid), $\left[\mathrm{Yb}^{\text {III }}(3,4,3-\mathrm{LI}(1,2-\mathrm{HOPO}))\right]^{-}$(dash dot). Spectra are normalized to the highest emission peak and emission peaks are labelled with the specific corresponding transition.

15
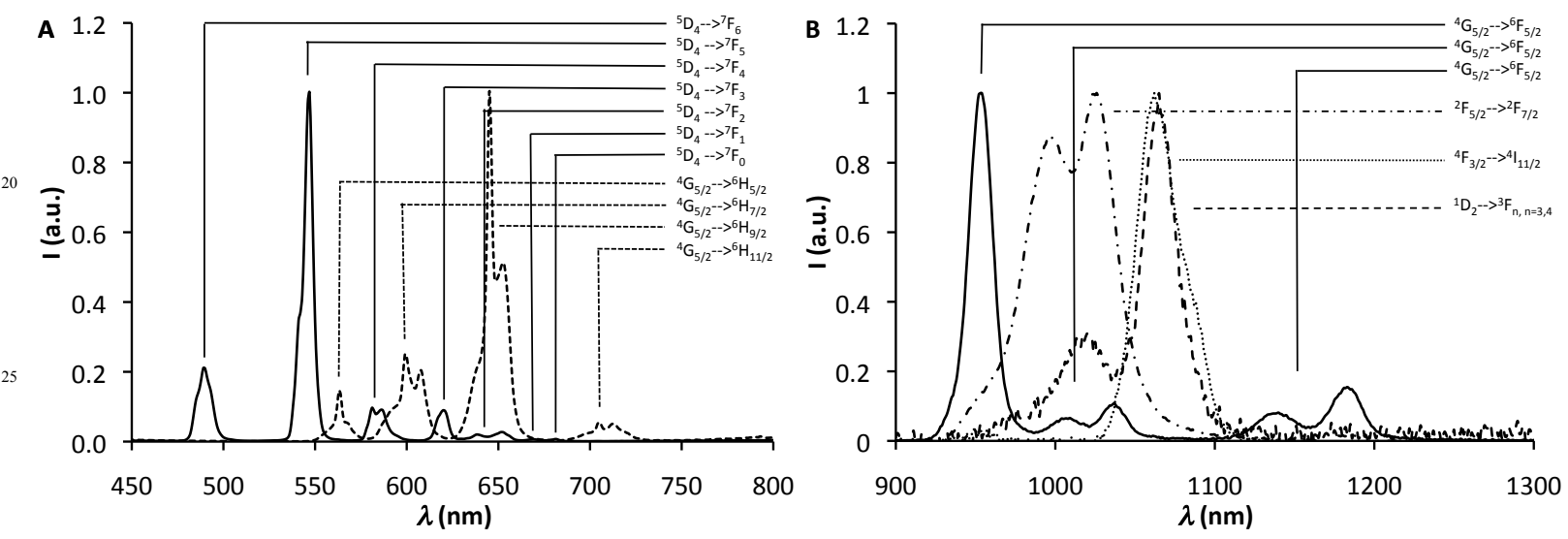

30

Based on the ligand triplet excited state determined previously, ${ }^{9} 3,4,3-\mathrm{LI}(1,2-\mathrm{HOPO})$ was expected to sensitize the luminescence of most lanthanides other than $\mathrm{Eu}^{\mathrm{III}}$, except $\mathrm{La}^{\mathrm{III}}$ (no f-electron), $\mathrm{Lu}^{\mathrm{III}}$ (full electron shell), $\mathrm{Gd}^{\mathrm{III}}$ and $\mathrm{Tm}^{\mathrm{III}}$ (emitting f-orbitals higher in energy). ${ }^{22}$ Sensitized emission was observed in the visible range for the $\mathrm{Sm}^{\mathrm{III}}$ and $\mathrm{Tb}^{\mathrm{III}}$ complexes and in the Near Infra-Red range for the Pr ${ }^{\mathrm{III}}$, ${ }_{35} \mathrm{Nd}^{\mathrm{III}}, \mathrm{Sm}^{\mathrm{III}}$, and $\mathrm{Yb}^{\mathrm{III}}$ complexes (Fig. 2), while no luminescence was observed for the $\mathrm{Dy}^{\mathrm{III}}, \mathrm{Ho}^{\mathrm{III}}$ and Er ${ }^{\mathrm{III}}$ complexes. Time-resolved analysis of the luminescence of the emitting complexes revealed monoexponential decays with decay times varying from $1.78 \mu \mathrm{s}$ to 805 $\mu$ s at room temperature. The luminescence quantum yields of the two complexes emitting in the visible, $\left[\mathrm{Sm}^{\mathrm{III}}(3,4,3-\mathrm{LI}(1,2-\mathrm{HOPO}))\right]^{-}$ and $\left[\mathrm{Tb}^{\mathrm{III}}(3,4,3-\mathrm{LI}(1,2-\mathrm{HOPO}))\right]^{-}$, were both determined with the optically dilute method (with optical density $\left.<0.1\right)$; the resulting values $\left(\Phi_{\text {tot }}=0.2 \%\right.$ for both) were significantly lower than that of the Eu ${ }^{\text {III }}$ complex $(7.0 \%),{ }^{9}$ which can be attributed to the closeness between 40 the ligand triplet excited state and the emitting excited states of $\mathrm{Sm}^{\mathrm{III}}$ and $\mathrm{Tb}^{\mathrm{III}}$, and the corresponding energy transfer/back-transfer processes.

\section{Solution Thermodynamics}

A direct spectrofluorimetric titration method had been described previously to determine the Eu ${ }^{\text {III }}$ complex formation constants for 3,4,3LI(1,2-HOPO). ${ }^{9}$ The spectral measurements relied on the sensitization of the Eu luminescence by the excited ligand: the emission 45 intensity of a solution containing equimolar amounts of $\mathrm{Eu}^{\mathrm{III}}$ and ligand increased upon $\mathrm{pH}$ increase and resulting complex formation (Fig. 3). The Eu ${ }^{\text {III }}$ complex formation constants were re-determined in this work, following this direct spectrofluorimetric method, ${ }^{9}$ with modified additional titrant increments that allowed more accurate measurements (Table 2). 


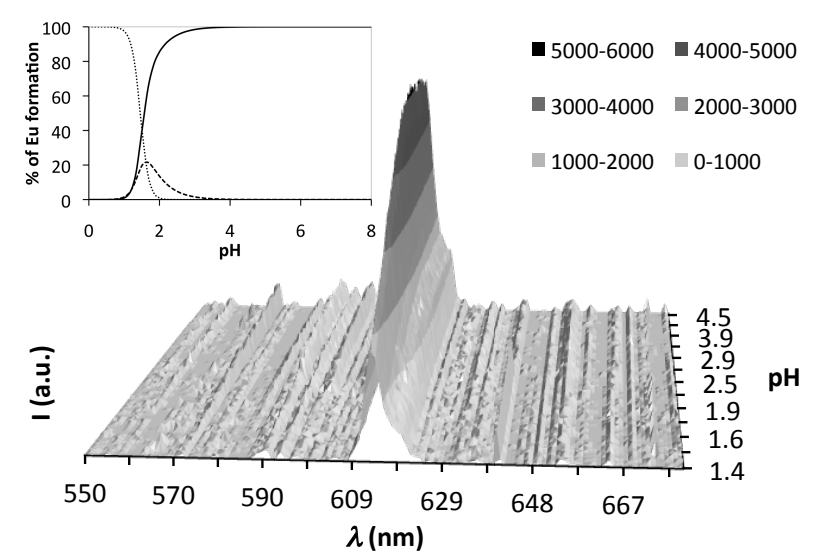

Fig. 3 Re-determination of the stability constants of the $\left[\mathrm{Eu}^{\text {III }}(3,4,3-\mathrm{LI}(1,2-\mathrm{HOPO})]^{-}\right.$complex through direct spectrofluorimetric titration $\left(\left[\mathrm{Eu}{ }^{\mathrm{III}}\right]=\right.$ $[3,4,3-\mathrm{LI}(1,2-\mathrm{HOPO})]=0.05 \mathrm{mM}, 0.1 \mathrm{M} \mathrm{KCl}, 10 \mathrm{mM} \mathrm{MES}, 10 \mathrm{mM}$ acetic acid, $25^{\circ} \mathrm{C}, \lambda_{\mathrm{exc}}=325 \mathrm{~nm}, \mathrm{pH} 1.3$ to 10$)$. Emission spectra shown for the $\mathrm{pH}$ range of $1.4-4.5$; the luminescence signal increases with the $\mathrm{pH}$, which allows the determination of the stability constants. ${ }^{9}$ Inset. Eu species distribution 5 in the titration conditions: dotted line $=$ free $\mathrm{Eu}$; dashed line $=\mathrm{EuLH}$; solid line $=\mathrm{EuL}^{-}$.

Table 2. Protonation and Eu ${ }^{\text {III }}$ Complex Formation Constants for 3,4,3-LI(1,2-HOPO).

\begin{tabular}{ccc}
\hline species & $m . l, h$ & $\log \beta_{m l h}$ \\
\hline $\mathrm{LH}$ & $0,1,1$ & $6.64(1)^{[\mathrm{a}]}$ \\
$\mathrm{LH}_{2}$ & $0,1,2$ & $12.32(1)^{[\mathrm{a}]}$ \\
$\mathrm{LH}_{3}$ & $0,1,3$ & $17.33(1)^{[\mathrm{a}]}$ \\
$\mathrm{LH}_{4}$ & $0,1,4$ & $21.20(1)^{[\mathrm{a}]}$ \\
EuL & $1,1,0$ & $20.2(2)^{[\mathrm{b}]}$ \\
EuLH & $1,1,1$ & $21.4(2)^{[\mathrm{b}]}$ \\
pEu $^{[I I}$ & & $21.1(2)^{[\mathrm{b}]}$
\end{tabular}

${ }^{[a]}$ Previously determined and reported. ${ }^{9}$

${ }^{[b]}$ Values experimentally determined in this work, following a previously reported method ${ }^{9}$ with modified additional titrant increments for more accurate measurements.

10

As only two lanthanides other than $\mathrm{Eu}^{\mathrm{III}}$ are sensitized by 3,4,3-LI(1,2-HOPO) to emit luminescence in the visible, with very low quantum yields, a systematic determination of the stability constants of each complex was not possible through the direct titration method. However, proton-independent stability constants $\left(K_{\mathrm{ML}}=\beta_{110}\right)$ and corresponding conditional stability constants (calculated and reported as $\mathrm{pM}$ values) ${ }^{\ddagger}$ for the lanthanide series could be determined indirectly through metal competition titrations (Table 1), using ${ }_{15} \mathrm{Eu}^{\mathrm{III}}$ as a reference because of its central position in the series and the remarkable luminescence properties of the corresponding 3,4,3$\mathrm{LI}(1,2-\mathrm{HOPO})$ complex. In these competition titrations, solutions containing an equimolar ratio of $\mathrm{Eu}^{\mathrm{III}}$ and $3,4,3-\mathrm{LI}(1,2-\mathrm{HOPO})\left(\left[\mathrm{Eu}{ }^{\mathrm{III}}\right]\right.$ $=[3,4,3-\operatorname{LI}(1,2-$

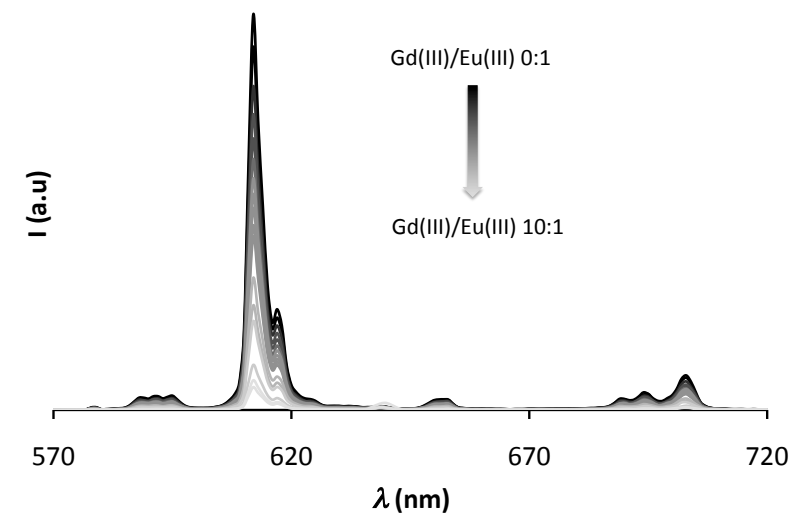

Fig. 4 Spectrofluorimetric competition titration of $\left[\mathrm{Eu}^{\mathrm{III}}(3,4,3-\mathrm{LI}(1,2-\mathrm{HOPO}))\right]^{-}$against $\mathrm{Gd}(\mathrm{III})$. [Eu $\left.{ }^{\mathrm{III}}\right]=[3,4,3-\mathrm{LI}(1,2-\mathrm{HOPO})]=5 \mu \mathrm{M},\left[\mathrm{Gd}{ }^{\mathrm{III}}\right]=0$ $200.05 \mathrm{mM}, 0.1 \mathrm{M} \mathrm{KCl}, 0.1 \mathrm{M} \mathrm{HEPES}, \mathrm{pH}=7.4,25.0^{\circ} \mathrm{C}, \lambda_{\mathrm{exc}}=325 \mathrm{~nm}$. The luminescence signal resulting from the sensitization of Eu ${ }^{\text {III }}$ by $3,4,3-\mathrm{LI}(1,2-$ $\mathrm{HOPO}$ ) decreases while the $\mathrm{Gd}^{\mathrm{III}}$ concentration increases

$\mathrm{HOPO})]=5 \mu \mathrm{M},[\mathrm{KCl}]=0.1 \mathrm{M},[\mathrm{HEPES}]=0.1 \mathrm{M}, \mathrm{pH} 7.4,25.0^{\circ} \mathrm{C}$ ) were divided into separate aliquots and the studied lanthanide was added to reach concentrations varying from 0 to $5 \mathrm{mM}$. The solutions were allowed to reach equilibrium (when no luminescence change ${ }_{25}$ was observed $)$ and the emission spectra recorded $\left(\lambda_{\text {exc }}=325 \mathrm{~nm}\right)$. The intensity of the $\left[\mathrm{Eu}^{\mathrm{III}}(3,4,3-\mathrm{LI}(1,2-\mathrm{HOPO}))\right]^{-}$emission decreases 
upon addition of the competing lanthanide (Fig. 4), dependent on its affinity for the ligand, and corresponding to the formation of the new complex. The data consisting of sets of emission spectra $\left(\lambda_{\mathrm{em}}=570-720 \mathrm{~nm}\right)$ with varying concentrations of competing lanthanide ion were imported into the refinement program HypSpec ${ }^{15}$ and analyzed by nonlinear least-squares refinements. The equilibration of 3,4,3-LI(1,2-HOPO) between $\mathrm{Eu}^{\mathrm{III}}$ and the competing metal was calculated by including the proton association and Eu ${ }^{\mathrm{III}}$ complex

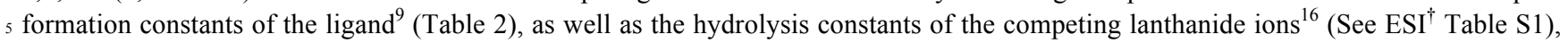
as fixed parameters in the refinements, with the emission intensity resulting exclusively from the sensitization of $\mathrm{Eu}^{\mathrm{III}}, \mathrm{Sm}^{\mathrm{III}}$, or $\mathrm{Tb}^{\mathrm{III}}$ by 3,4,3-LI(1,2-HOPO). The refined complex formation constants and corresponding pM values are reported in Table 1.

\section{Stability Increase Along the Lanthanide Series}

The stability of the $\left[\operatorname{Ln}^{\mathrm{III}}(3,4,3-\mathrm{LI}(1,2-\mathrm{HOPO}))\right]^{-}$complexes increases along the lanthanide series (Table 1 and Fig. 5), an effect that can 10 be attributed to different reasons: (i) the cation radii size, which decreases along the series, ${ }^{23,24}$ (ii) the coordination number of the lanthanide, which can vary from 9 to 8 , and thus the number of water molecules in the complex inner sphere, ${ }^{25,26}$ and (iii) the Lewis acidity of the metal, which increases along the series. ${ }^{27}$ The number of inner sphere water molecules in the Eu ${ }^{\text {III }}$ complex was determined previously as zero, ${ }^{9}$ using the luminescence-based Horrocks equation, ${ }^{28}$ which could not be reliably applied to the other lanthanides. Mass spectrometry was used to characterize the complexes and determine the corresponding coordination number. However, only 815 coordinated complexes could be confirmed in negative ion mode (Fig. 6 and ESI ${ }^{\dagger}$ Table S2).

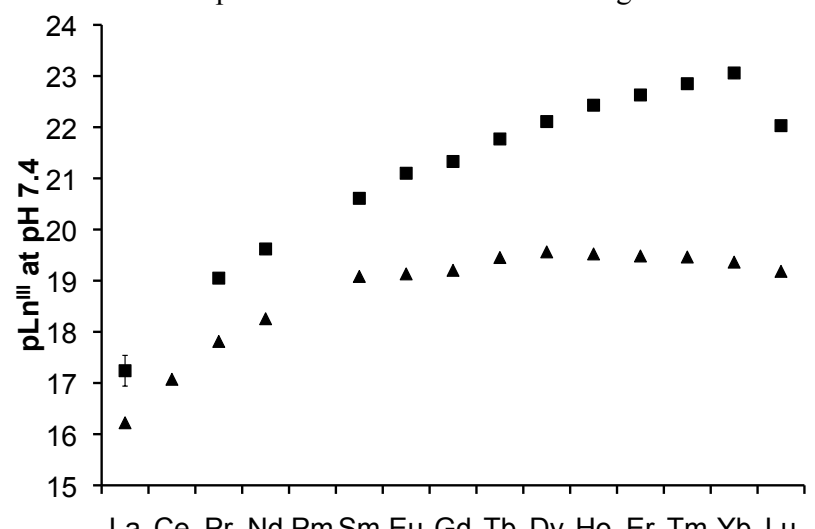

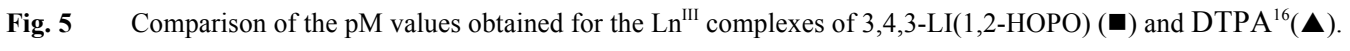

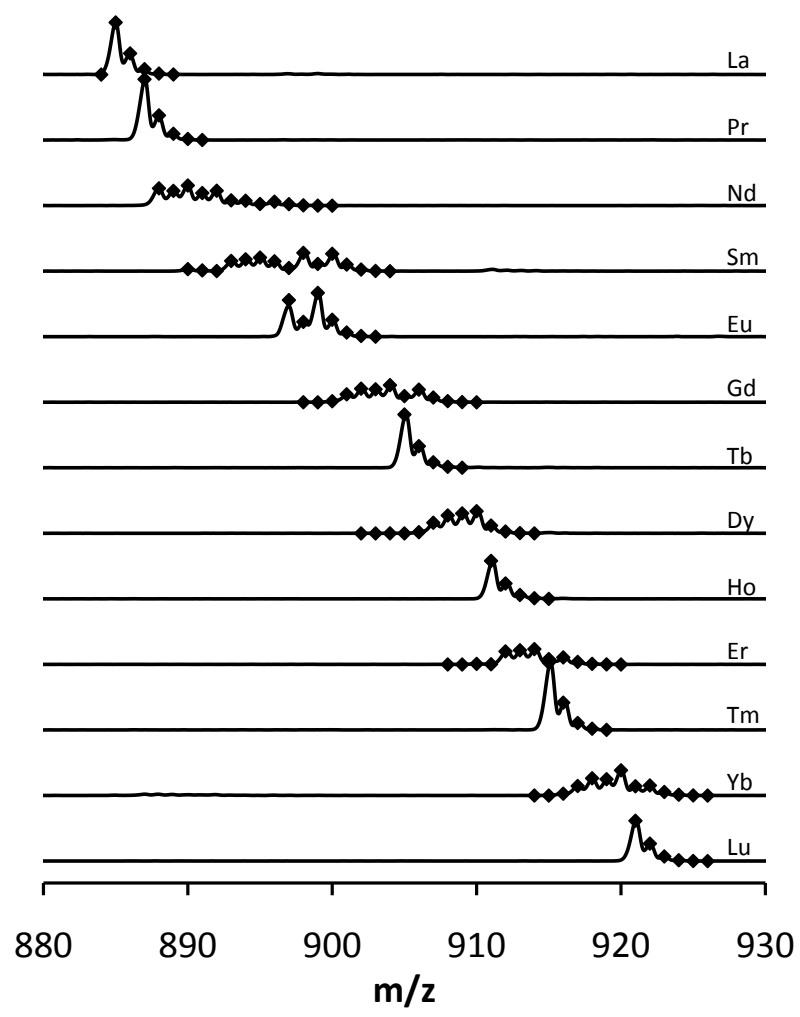

Fig. 6 Mass spectra of $50 \mu \mathrm{M}\left[\mathrm{Ln}^{\mathrm{III}}(3,4,3 \mathrm{LI}-(1,2-\mathrm{HOPO}))\right]^{-}$solutions directly injected in the ESI-MS at $\mathrm{pH}=7.4$ (solid lines). The diamonds 20 represent the theoretical calculated isotope patterns for the complexes. 
If an additional water molecule was bound to the metal center, it might be too labile and released during the spraying process. Other techniques such as NMR or X-ray absorption spectroscopies may be used in the future to characterize and compare the coordination spheres of these metal complexes.

${ }_{5}$ The in vivo distribution patterns and biokinetics of the lanthanides have been investigated previously, ${ }^{29,30}$ revealing an increase in bone retention and a decrease in liver deposition along the lanthanide series. These patterns may be linked to an increase in lanthanide complex stability with the phosphate binding moieties of the bone matrices, similar to the stability increases observed with 3,4,3-LI(1,2HOPO), as the metal ion becomes smaller and more acidic. The use of pM values also allows for comparisons between different ligands: the affinity of 3,4,3-LI(1,2-HOPO) for lanthanide cations is remarkably high and at least 1.5 orders of magnitude higher than that of ${ }_{10}$ DTPA $^{16}$ (Fig. 5). In addition, citrate is a low molecular weight biological ligand that may play a predominant role in lanthanide in vivo speciation. ${ }^{31}$ However, the stabilities of citrate-lanthanide complexes (pM ranging from 8.3 for La ${ }^{\text {III }}$ to 9.0 for $\mathrm{Yb}^{\mathrm{III}}$ ) ${ }^{16}$ are substantially lower than those determined with 3,4,3-LI(1,2-HOPO). The octadentate hydroxypyridonate chelator can therefore form some of the strongest complexes so far identified with the trivalent metal ions of the lanthanide series, which makes it an excellent candidate for decorporation applications.

\section{In Vivo Decorporation and Stability}

To evaluate the efficacy of 3,4,3-LI(1,2-HOPO) at forming stable in vivo Eu ${ }^{\text {III }}$ complexes and at promoting Eu decorporation, the designed experimental protocols used a ${ }^{152} \mathrm{Eu}$ radiolabel, as well as $\mathrm{CaNa}_{3} \mathrm{DTPA}$-treated and untreated control groups. In the decorporation experiment, ${ }^{152} \mathrm{Eu}^{\mathrm{III}}$ was administered intravenously as a chloride solution $(0.008 \mathrm{M}$ sodium citrate, $0.14 \mathrm{M} \mathrm{NaCl}, \mathrm{pH} 4)$, and the ligands were injected intraperitoneally $1 \mathrm{~h}$ later. In the in vivo stability experiment, ${ }^{152} \mathrm{Eu}$-ligand complexes were formed in situ 20 (Ligand:Eu ratio > 20) and administered intravenously. Mice were euthanized $24 \mathrm{~h}$ after the metal injection, and blood, tissues, and excreta were radioanalyzed for ${ }^{152}$ Eu content (See ESI ${ }^{\dagger}$ Tables S3 and S4).

When 3,4,3-LI(1,2-HOPO) was administered as a chelating agent, the 24-hour ${ }^{152} \mathrm{Eu}$ body content was significantly reduced to $18 \%$ of the injected dose, in comparison to 54 and $67 \%$ for $\mathrm{CaNa}_{3} \mathrm{DTPA}$-treated and untreated control groups, respectively (Fig. 7). The ${ }^{152}$ Eu content in the liver and skeleton of mice treated with the experimental ligand was also considerably lower than that in mice treated with ${ }_{25} \mathrm{CaNa}_{3} \mathrm{DTPA}$. In contrary to $\mathrm{CaNa}_{3} \mathrm{DTPA}, 3,4,3-\mathrm{LI}(1,2-\mathrm{HOPO})$ promoted ${ }^{152} \mathrm{Eu}$ decorporation through a predominant fecal excretion pathway ( $\sim 64 \%$ of the total excretion). These different excretion patterns were also observed in the complex stability experiment: more than $99 \%$ of the injected complexes were excreted after 24 hours in both cases, however for the DTPA complex ${ }^{152}$ Eu was mostly found in the urine while nearly $90 \%$ of the ${ }^{152} \mathrm{Eu}$ for the-3,4,3-LI(1,2-HOPO) complex was detected in the feces (Fig. 7). The ${ }^{152} \mathrm{Eu}$ decorporation process must therefore follow two different biochemical pathways for both ligands, probably due to the respective 30 membrane permeability properties of the ligands. Overall, these results corroborate the thermodynamic stability constants corresponding to the $\mathrm{Eu}(\mathrm{III})$ complexes of DTPA and 3,4,3-LI(1,2-HOPO): while both ligands form highly stable complexes in vivo, the hydroxypyridonate ligand 3,4,3-LI(1,2-HOPO) has a higher affinity for Eu(III) that enhances its capability to compete with biological ligands such as proteins and bone matrices and thereby its decorporation properties, as compared to DTPA.

\section{Conclusions}

35 The stability constants of the lanthanide complexes formed with the hydroxypyridonate ligand 3,4,3-LI(1,2-HOPO) were determined through a new indirect spectrofluorimetric titration method using the remarkable lanthanide luminescence sensitization properties of this chelator.

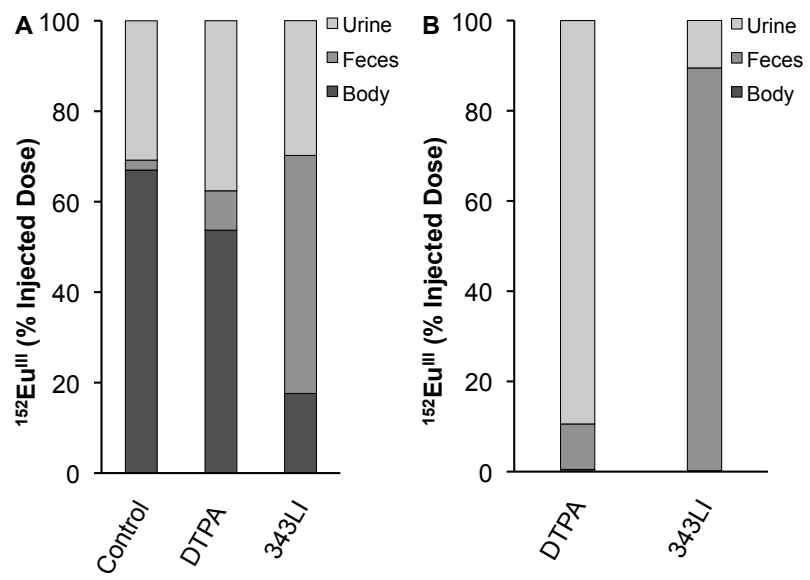

Fig. 7 A) Decorporation of ${ }^{152} \mathrm{Eu}$ promoted by injected ligands. Normal mice injected intravenously with ${ }^{152} \mathrm{Eu}$; ligands $\left(30 \mu \mathrm{mol} \mathrm{kg}^{-1}\right)$ injected 40 intraperitoneally 1 hour later; mice euthanized at 24 hours. B) In vivo stability of ${ }^{152} \mathrm{Eu}$ complexes of DTPA and 3,4,3-LI(1,2-HOPO). Normal mice injected intravenously with ${ }^{152}$ Eu-ligand complexes; mice euthanized at 24 hours. 
The high affinity of this chelator for lanthanides, as compared to DTPA, indicates its potential as a therapeutic chelating agent for f-block metal ions, which was confirmed through the first in vivo decorporation and stability experiments using the radiotracer ${ }^{152} \mathrm{Eu}$, a common fission product in the nuclear fuel process. Other radionuclides potentially targeted by 3,4,3-LI(1,2-HOPO) include tri- and tetravalent actinides such as $\mathrm{Pu}(\mathrm{IV})$ and $\mathrm{Am}(\mathrm{III})$. The analytical methods used here will be applied to the determination of the photophysical ${ }_{5}$ properties and thermodynamic parameters of the corresponding 3,4,3-LI(1,2-HOPO) complexes, providing a rationale to the use and design of new decorporation agents. In addition, sensing f-block metal ions through luminescence spectroscopy has the potential to ease and significantly improve current actinide detection and characterization methods in terms of selectivity and accuracy.

\section{Acknowledgements}

This research was supported by the National Institutes of Health (Lanthanide and Actinide Decorporation Program, Grants AI074065-01, 10 1RC2AI087604-01 and 5RC2AI087604-02), the Director, Office of Science, Office of Basic Energy Sciences, the Division of Chemical Sciences, Geosciences and Biosciences of the U.S. Department of Energy at LBNL under Contract No. De-AC02-05CH11231 (Lanthanide and Actinide Luminescence Studies).

\section{References}

1. P. W. Durbin, Health Phys., 2008, 95, 465-492.

15 2. E. G. Moore, C. J. Jocher, J. Xu, E. J. Werner, and K. N. Raymond, Inorg. Chem., 2007, 46, 5468-5470.

3. E. G. Moore, A. P. S. Samuel, and K. N. Raymond, Acc. Chem. Res., 2009, 42, 542-552.

4. R. C. Scarrow, P. E. Riley, K. Abu-Dari, D. L. White, and K. N. Raymond, Inorg. Chem., 1985, 24, 954-967.

5. E. J. Werner, A. Datta, C. J. Jocher, and K. N. Raymond, Angew. Chem. Int. Ed., 2008, 47, 8568-8580.

6. R. J. Abergel, P. W. Durbin, B. Kullgren, S. N. Ebbe, J. Xu, P. Y. Chang, D. I. Bunin, E. A. Blakely, K. A. Bjornstad, C. J. Rosen, D. K. Shuh, and K. 20 N. Raymond, Health Phys., 2010, 99, 401-407.

7. P. W. Durbin, B. Kullgren, S. N. Ebbe, J. Xu, and K. N. Raymond, Health Phys., 2000, 78, 511.

8. R. J. Abergel and K. N. Raymond, Hemoglobin, 2011, 35.

9. R. J. Abergel, A. D’Aleo, C. Ng Pak Leung, D. K. Shuh, and K. N. Raymond, Inorg. Chem., 2009, 48, 10868-10870.

10. P. Gans and B. O'Sullivan, Talanta, 2000, 51, 33-37.

25 11. P. Gans, A. Sabatini, and A. Vacca, pHab20003, Leeds, U.K. Florence, Italy.

12. P. Gans, A. Sabatini, and A. Vacca, HYPERQUAD2000, Leeds, U.K. Florence, Italy.

13. P. Gans, A. Sabatini, and A. Vacca, Talanta, 1996, 43, 1739-1753.

14. P. Gans, A. Sabatini, and A. Vacca, Ann. Chim., 1999, 89, 45-49.

15. P. Gans, A. Sabatini, and A. Vacca, HypSpec, Leeds, U.K. Florence, Italy.

30 16. A. E. Martell, R. M. Smith, and R. J. Motekaitis, NIST Standard Reference Database 46, .

17. L. Alderighi, P. Gans, A. Ienco, D. Peters, A. Sabatini, and A. Vacca, Coord. Chem. Rev., 1999, 184, 311-318.

18. L. Alderighi, P. Gans, A. Ienco, D. Peters, A. Sabatini, and A. Vacca, HYSS, Leeds, U.K. Florence, Italy.

19. P. W. Durbin, N. Jeung, B. Kullgren, and G. K. Clemons, Health Phys., 1992, 63, 427-442.

20. P. W. Durbin, B. Kullgren, J. Xu, and K. N. Raymond, Radiat. Protect. Dosim., 1994, 53, 305-309.

35 21. P. W. Durbin, B. Kullgren, J. Xu, K. N. Raymond, P. G. Allen, J. J. Bucher, N. M. Edelstein, and D. K. Shuh, Health Phys., 1998, 75, 34-50.

22. J.-C. G. Bünzli and C. Piguet, Chem. Soc. Rev., 2005, 34, 1048.

23. M. Seitz, A. G. Oliver, and K. N. Raymond, J. Am. Chem. Soc., 2007, 129, 11153-11160.

24. R. D. Shannon, Acta Chryst. A, 1976, 32, 751-767.

25. K. Djanashvili and J. A. Peters, Contrast Media Mol. Imaging, 2007, 2, 67-71.

40 26. K. Djanashvili, C. Platas-Iglesias, and J. A. Peters, Dalton Trans., 2008, 602.

27. H. Tsuruta, K. Yamaguchi, and T. Imamoto, Tetrahed., 2003, 59, 10419-10438.

28. R. M. Supkowski and W. D. Horrocks, Inorg. Chim. Acta, 2002, 340, 44-48.

29. P. W. Durbin, Health Phys., 1960, 2, 225.

30. D. M. Taylor and R. W. Leggett, Radiat. Protect. Dosim., 2003, 105, $193-198$.

45 31. A. Heller, A. Barkleit, and G. Bernhard, Chem. Res. Toxicol., 2011, 24, 193-203. 


\title{
3,4,3-LI(1,2-HOPO): In Vitro Formation of Highly Stable Lanthanide Complexes Translates into Efficacious In Vivo Europium Decorporation
}

\author{
Manuel Sturzbecher-Hoehne, ${ }^{a}$ Clara Ng Pak Leung, ${ }^{a}$ Anthony D’Aléo, ${ }^{a}$ Birgitta Kullgren, ${ }^{a}$ Anne-Laure \\ Prigent, ${ }^{a}$ David K. Shuh, ${ }^{a}$ Kenneth N. Raymond ${ }^{a, b}$ and Rebecca J. Abergel ${ }^{* a}$ \\ ${ }^{a}$ Chemical Sciences Division, Lawrence Berkeley National Laboratory, Berkeley, CA 94720, USA. E-mail: rjabergel@1bl.gov; Fax: +1 510 486 5596; Tel: \\ $+15104865249$ \\ ${ }^{b}$ Department of Chemistry, University of California, Berkeley, CA 94720-1460, USA.
}

10

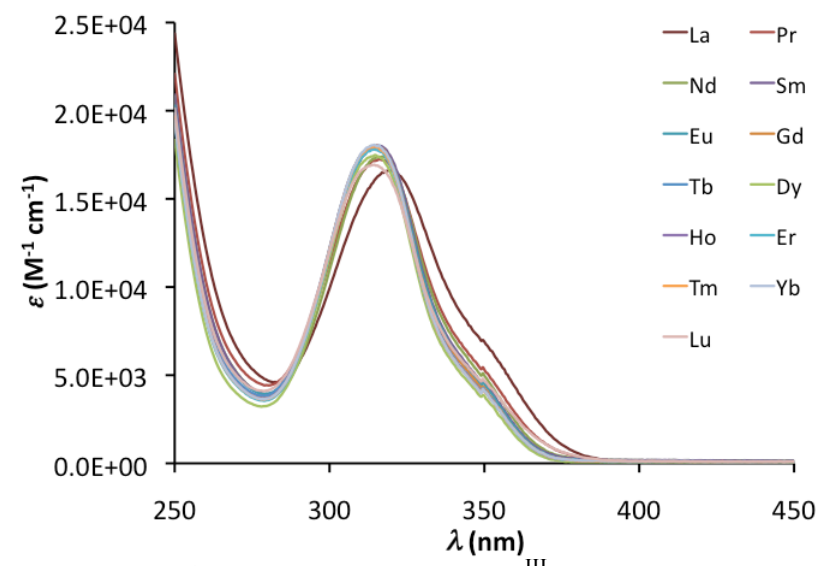

Figure S1. Absorption spectra of $\left[\operatorname{Ln}^{\mathrm{III}}(3,4,3-\mathrm{LI}(1,2-\mathrm{HOPO}))\right]^{-}$complexes in the visible, $\mathrm{pH}=7.4, I=0.1 \mathrm{M}(\mathrm{KCl})$. 15

${ }_{20}$ Table S1. Lanthanide Hydrolysis Constants Included in Stability Constants Refinement. ${ }^{a}$

\begin{tabular}{lccccccccccccc}
\hline Species & $\mathrm{La}$ & $\mathrm{Pr}$ & $\mathrm{Nd}$ & $\mathrm{Sm}$ & $\mathrm{Eu}$ & $\mathrm{Gd}$ & $\mathrm{Tb}$ & $\mathrm{Dy}$ & $\mathrm{Ho}$ & $\mathrm{Er}$ & $\mathrm{Tm}$ & $\mathrm{Yb}$ & $\mathrm{Lu}$ \\
\hline $\mathrm{MH}_{-1}{ }^{\mathrm{b}}$ & -8.8 & -8.3 & -8.2 & -8.1 & -8.1 & -8.1 & -7.9 & -7.9 & -7.8 & -7.7 & -7.7 & -7.7 & -7.4 \\
$\mathrm{MH}_{-2}{ }^{\mathrm{c}}$ & & -15.6 & -15.3 & & -14.4 & -14.5 & & -13.6 & & & & & \\
$\mathrm{MH}_{-3}{ }^{\mathrm{d}}$ & -20.3 & -22.3 & -23.2 & -23.9 & -24.5 & -24.1 & -24.3 & -23.9 & -24.5 & -24.7 & -24.7 & -24.7 & -25.1 \\
$\mathrm{M}_{2} \mathrm{H}_{-2}{ }^{\mathrm{c}}$ & -17.1 & & & -14.1 & & & & & & -13.1 & & -12.7 & \\
\hline
\end{tabular}

${ }^{a}$ All values are reported as $\log \beta$ and were previously reported in A. E. Martell, R. M. Smith, R. J. Motekaitis, NIST Critically Selected Stability Constants of Metal Complexes: Version 8.0.

${ }^{\mathrm{b}}$ The values for $\mathrm{MH}_{-1}$ are corrected for $I=0.1 \mathrm{M}$ with the help of the equation used in Klungness, G.D. and Byrne, R.H.

${ }_{25}$ Polyhedron, 2000, 19, 99-107.

${ }^{\mathrm{c}} I=2.0 \mathrm{M}$.

${ }^{\mathrm{d}} I=0.0 \mathrm{M}$. 
Table S2. Observed Mass-to-Charge Ratios for $\left[\operatorname{Ln}^{\mathrm{III}}(3,4,3-\mathrm{LI}(1,2-\mathrm{HOPO}))\right]^{-}$complexes at $\mathrm{pH} 7.4 .^{a}$

\begin{tabular}{ccc}
\hline Metal & Species & $\mathrm{m} / \mathrm{z}^{b}$ \\
\hline $\mathrm{La}$ & {$\left[\mathrm{La}^{\mathrm{III}}(3,4,3-\mathrm{LI}(1,2-\mathrm{HOPO}))\right]^{-}$} & 885 \\
$\mathrm{Pr}$ & {$\left[\mathrm{Pr}^{\mathrm{III}}(3,4,3-\mathrm{LI}(1,2-\mathrm{HOPO}))\right]^{-}$} & 887 \\
$\mathrm{Nd}$ & {$\left[\mathrm{Nd}^{\mathrm{III}}(3,4,3-\mathrm{LI}(1,2-\mathrm{HOPO}))\right]^{-}$} & 890 \\
$\mathrm{Sm}$ & {$\left[\mathrm{Sm}^{\mathrm{III}}(3,4,3-\mathrm{LI}(1,2-\mathrm{HOPO})]^{-}\right.$} & 898 \\
$\mathrm{Eu}$ & {$\left[\mathrm{Eu}^{\mathrm{III}}(3,4,3-\mathrm{LI}(1,2-\mathrm{HOPO}))\right]^{-}$} & 899 \\
$\mathrm{Gd}$ & {$\left[\mathrm{Gd}^{\mathrm{III}}(3,4,3-\mathrm{LI}(1,2-\mathrm{HOPO}))\right]^{-}$} & 904 \\
$\mathrm{~Tb}$ & {$\left[\mathrm{~Tb}^{\mathrm{III}}(3,4,3-\mathrm{LI}(1,2-\mathrm{HOPO}))\right]^{-}$} & 905 \\
$\mathrm{Dy}$ & {$\left[\mathrm{Dy}^{\mathrm{III}}(3,4,3-\mathrm{LI}(1,2-\mathrm{HOPO}))\right]^{-}$} & 910 \\
$\mathrm{Ho}$ & {$\left[\mathrm{Ho}^{\mathrm{III}}(3,4,3-\mathrm{LI}(1,2-\mathrm{HOPO}))\right]^{-}$} & 911 \\
$\mathrm{Er}$ & {$\left[\mathrm{Er}^{\mathrm{III}}(3,4,3-\mathrm{LI}(1,2-\mathrm{HOPO}))\right]^{-}$} & 914 \\
$\mathrm{Tm}$ & {$\left[\mathrm{Tm}^{\mathrm{III}}(3,4,3-\mathrm{LI}(1,2-\mathrm{HOPO}))\right]^{-}$} & 915 \\
$\mathrm{Yb}$ & {$\left[\mathrm{Yb}^{\mathrm{III}}(3,4,3-\mathrm{LI}(1,2-\mathrm{HOPO}))\right]^{-}$} & 920 \\
$\mathrm{Lu}$ & {$\left[\mathrm{Lu}^{\mathrm{III}}(3,4,3-\mathrm{LI}(1,2-\mathrm{HOPO}))\right]^{-}$} & 921 \\
\hline
\end{tabular}

${ }^{a}[3,4,3-\mathrm{LI}(1,2-\mathrm{HOPO})]=0.5 \mathrm{mM}\left[\mathrm{Ln}^{\mathrm{III}}\right]=0.05 \mathrm{mM}$, no buffer added.

${ }_{5}{ }^{b}$ Reported numbers correspond to the main peaks in each spectrum.

Table S3. Promotion of ${ }^{152} \mathrm{Eu}$ Excretion in Mice by Injected Octadentate Ligands. ${ }^{a}$

\begin{tabular}{|c|c|c|c|c|c|c|c|}
\hline \multirow[b]{2}{*}{ Ligand } & \multicolumn{5}{|c|}{$\begin{array}{l}\text { Fraction of injected }{ }^{152} \mathrm{Eu}(\%, \text { mean } \pm \mathrm{SD}) \text { at } 24 \mathrm{~h} \\
\text { Tissues }\end{array}$} & \multicolumn{2}{|c|}{ Excreta $^{b}$} \\
\hline & Liver & Skeleton & Soft tissue & Kidneys & Whole body & Feces & Urine \\
\hline Control & $0.7 \pm 1.93$ & $28.9 \pm 1.25$ & $6.29 \pm 0.90$ & $1.0 \pm 0.22$ & $67.0 \pm$ & 2.19 & 30.8 \\
\hline & & & & $0.78 \pm 0.09$ & & 8.71 & 37.6 \\
\hline 3,4,3-LI(1,2-HOPO) & $1.24 \pm 0.22$ & $12.8 \pm 0.47$ & $3.12 \pm 0.31$ & $0.44 \pm 0.10$ & $17.6 \pm 0.71$ & 52.6 & 29.8 \\
\hline
\end{tabular}

${ }_{10}{ }^{a}$ Groups of five mice were injected intravenously with ${ }^{152} \mathrm{Eu}$; mice were injected intraperitoneally with $30 \mu \mathrm{mol} / \mathrm{kg}$ of a ligand at $1 \mathrm{~h}$; control mice were given $0.14 \mathrm{M} \mathrm{NaCl}$ (normal saline) intraperitoneally; mice were euthanized at $24 \mathrm{~h}$. Data, expressed as percent of injected ${ }^{152} \mathrm{Eu}(\%$, mean $\pm \mathrm{SD})$, were normalized to $100 \%$ material recovery for each five-mouse group. Discrepancies are due to rounding. $\mathrm{SD}=\left[\Sigma \operatorname{dev}^{2}(\mathrm{n}-1)^{-1}\right]^{1 / 2}$; for tissues, $\mathrm{n}=$ number of mice.

${ }^{b}$ Excreta of each five-mouse group were pooled; no SD is available.

15

Table S4. In Vivo Stability of Intraperitoneally Injected ${ }^{152} \mathrm{Eu}$ Complexes. ${ }^{a}$

Fraction of injected ${ }^{152} \mathrm{Eu}(\%$, mean $\pm \mathrm{SD})$ at $24 \mathrm{~h}$

Tissues Excreta $^{b}$

\begin{tabular}{ccccccccc} 
Ligand & Liver & Skeleton & Soft tissue & Kidneys & Whole body & Feces & Urine \\
\hline DTPA & $0.09 \pm 0.02$ & $0.07 \pm 0.05$ & $0.22 \pm 0.11$ & $0.11 \pm 0.025$ & $0.49 \pm 0.12$ & 10.1 & 89.4 \\
$3,4,3-$ LI(1,2-HOPO) & $0.05 \pm 0.03$ & $0.02 \pm 0.03$ & $0.10 \pm 0.04$ & $0.022 \pm 0.004$ & $0.20 \pm 0.07$ & 89.3 & 10.5
\end{tabular}

${ }^{a}$ Groups of five mice were injected intraperitoneally with ${ }^{152} \mathrm{Eu}$-ligand complexes; $5 \mu \mathrm{mol} / \mathrm{kg}$ of ligand; ligand:Eu molar ${ }_{20}$ ratio $>20$; mice were euthanized at $24 \mathrm{~h}$. Data, expressed as percent of injected ${ }^{152} \mathrm{Eu}(\%$, mean \pm SD), were normalized to $100 \%$ material recovery for each five-mouse group. Discrepancies are due to rounding. $\mathrm{SD}=\left[\sum \operatorname{dev}^{2}(\mathrm{n}-1)^{-1}\right]^{1 / 2} ;$ for tissues, $\mathrm{n}=$ number of mice.

${ }^{b}$ Excreta of each five-mouse group were pooled; no SD is available. 